\title{
Protective effect of Cordyceps polysaccharide on hydrogen peroxide-induced mitochondrial dysfunction in HL-7702 cells
}

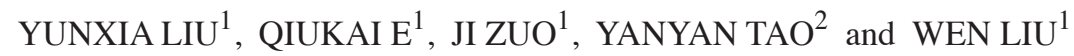 \\ ${ }^{1}$ Department of Cellular and Genetic Medicine, Shanghai Medical College, Fudan University, Shanghai 200032; \\ ${ }^{2}$ Institute of Liver Diseases, Shuguang Hospital Affiliated to Shanghai University of Traditional Chinese Medicine, \\ Shanghai 310000 , P.R. China
}

Received July 20, 2012; Accepted November 6, 2012

DOI: $10.3892 / \mathrm{mmr} .2012 .1248$

\begin{abstract}
Multiple reports have suggested that reactive oxygen species (ROS) are implicated in hepatic fibrosis and that they are capable of causing hepatocyte apoptosis in hepatic fibrosis by causing oxidative damage to the liver. Thus, the study of antioxidant compounds may shed light on the treatment of hepatic fibrosis. The aim of the current study was to investigate the protective effects of Cordyceps polysaccharide (CPS), a major antioxidative component of Cordyceps militaris, on hydrogen peroxide $\left(\mathrm{H}_{2} \mathrm{O}_{2}\right)$-induced cell apoptosis. The data showed that CPS markedly inhibited $\mathrm{H}_{2} \mathrm{O}_{2}$-induced mitochondrial dysfunction, lowered cell viability, increased the apoptotic rate, boosted ROS production, decreased mitochondrial membrane potential (MMP), reduced the intracellular adenosine triphosphate (ATP) level, increased the $\mathrm{Bax} / \mathrm{Bcl}-2$ ratio and promoted cytochrome $\mathrm{C}$ (Cyt $\mathrm{C}$ ) release. These results indicated that CPS protected HL-7702 cells, which are used as the main model of hepatic fibrosis, against $\mathrm{H}_{2} \mathrm{O}_{2}$-induced mitochondrial dysfunction by decreasing ROS production and regulating mitochondrial apoptotic signaling through the Cyt C, Bax and Bcl-2 apoptosis-related proteins.
\end{abstract}

\section{Introduction}

Hepatic fibrosis can be considered as a wound-healing response to chronic liver injury, and oxidative stress plays a significant role in the pathogenesis of liver diseases. Hepatocyte apoptosis is caused by hydrogen peroxide $\left(\mathrm{H}_{2} \mathrm{O}_{2}\right)$, which is attributed to heightened production of reactive oxygen species (ROS) and defects in the cellular antioxidant systems. ROS overproduction may cause hepatocyte apoptosis, which plays a central role in liver fibrosis (1-3). It is expected that certain natural

Correspondence to: Professor Wen Liu, Department of Cellular and Genetic Medicine, Shanghai Medical College, Fudan University, No. 130 Dongan Road, Shanghai 200032, P.R. China

E-mail: liuwen@shmu.edu.cn

Key words: cordyceps polysaccharide, mitochondrial dysfunction, oxidative stress, hydrogen peroxide, hepatocyte apoptosis antioxidants may act as potential anti-fibrotic agents that protect hepatocytes against ROS.

Cordyceps polysaccharide (CPS) is a major aqueous extract component of the Chinese herb summer grass and winter worm (Cordyceps militaris), which has been widely used as a tonic for longevity, endurance and vitality (4). Previous studies have shown that polysaccharides from various Cordyceps species have many useful biological activities including antitumor $(5,6)$, anti-influenza virus (7), immunopotentiation (8), hypoglycemic (9), hypocholesterolemic (10) and anti-oxidant effects (11-13). Multiple studies have shown that CPS is capable of increasing the activities of antioxidant enzymes such as catalase (CAT), superoxide dismutase (SOD) and glutathione peroxide (GPx), and effectively scavenges free radicals such as hydroxyl and superoxide anion radicals, which are byproducts of the mitochondrial electron transfer chain (ETC) (14).

Mitochondria play many pivotal functions, such as being the site of election transfer chain, oxidative phosphorylation and ATP synthesis, and mainly participate in cell apoptosis regulation (15). Mitochondria are also primary sites for ROS production, which gives rise to mitochondrial dysfunction. High ROS levels in cells lead to depolarization of mitochondrial membrane potential (MMP) and the loss of MMP subsequently triggers $\mathrm{Cyt} C$ release from mitochondria to the cytosol (16). The release of Cyt C impacts functions of respiratory chain complexes III and IV, which interrupts cellular electron flow, subsequently suppressing ATP generation and promoting cell apoptosis $(17,18)$. Mitochondria are considered the pacemakers of tissue diseases due to the continuous production of oxygen free radicals, nitrogen free radicals and related reactive species, and the selective oxidative damage that leads to mitochondrial dysfunction. However, the hepatocyte protective effects of CPS on $\mathrm{H}_{2} \mathrm{O}_{2}$-induced mitochondrial dysfunction remain unknown. In the present study, the aim was to evaluate whether CPS elicits protective actions against HL-7702 cell apoptosis induced by $\mathrm{H}_{2} \mathrm{O}_{2}$ through focusing on mitochondrial dysfunction.

\section{Materials and methods}

Materials. HL-7702 cells were purchased from the Institute of Biochemistry and Cell Biology, China Academy of Science, Shanghai. Cordyceps polysaccharide, obtained from 
Shanghai University of Traditional Chinese Medicine, was dissolved in sterile distilled water. 3-(4,5-dimethylthiazol2-yl) -2,5-diphenyltetrazolium bromide (MTT) was purchased from Sigma-Aldrich (St. Louis, MO, USA). Dimethlysulfoxide (DMSO) was obtained from Shenggong Biology (Shanghai, China). Mitochondrial membrane potential detection kit, ATP detection kit and Hoechst 33258 were purchased from Beyotime (Jiangsu, China). Dulbecco's modified Eagle's medium (DMEM) supplement was obtained from Gibco Invitrogen Co. (Gaithersburg, MD, USA). The fluorescent dye 2',7'-dichlorodihydro-fluorescein diacetate (H2DCF-DA) was purchased from Invitrogen. Antibodies against $\mathrm{Cyt} C$ were from Cell Signaling Technology (Beverly, MA, USA) and Epitomics (Burlingame, CA, USA). Antibodies against Bcl-2 and Bax were purchased from Epitomics. All the other chemicals were of the highest grade of purity available commercially.

Cell culture and treatment. HL-7702 cells were routinely cultured in DMEM (Gibco) containing 10\% fetal calf serum (FBS; Gibco), $100 \mathrm{U} / \mathrm{ml}$ penicillin and $100 \mathrm{mg} / \mathrm{ml}$ streptomycin and maintained in a humidified $5 \% \mathrm{CO}_{2}$ atmosphere at $37^{\circ} \mathrm{C}$. The medium was changed every two days. Cells were incubated with $400 \mu \mathrm{M} \mathrm{H}_{2} \mathrm{O}_{2}$ for $2 \mathrm{~h}$ to induce cell apoptosis. In order to study the effects of CPS, cells were pre-incubated with various concentrations of CPS for $2 \mathrm{~h}$, and then $\mathrm{H}_{2} \mathrm{O}_{2}$ was added to the medium for another $2 \mathrm{~h}$.

Isolation and purification of CPS. The dried powder of cultured cordyceps mycelia was purchased from Traditional Chinese Medicine Limited Liability Company (Jiangxi, China) and was defatted with various concentrations of ethanol. The extract was boiled twelve times in water for $2 \mathrm{~h}$ and centrifuged; the supernatant was concentrated and treated with 15 times volume of ethanol for precipitation. The precipitate was suspended in water, dialyzed and lyophilized to yield the crude polysaccharide-enriched fraction. The extraction ratio of crude polysaccharide was $15 \%$ and the purity was above 99\%. The crude polysaccharide verified by Fehling Reagent, mainly contained reductive sugars such as mannose, galactose glucose, cordycepin, adenosine, arabinose, xylose and fucose, and these monosaccharides composed the polysaccharide.

Preparation of CPS stock solution. The stock solution of CPS was prepared by dissolving $10 \mathrm{mg}$ CPS using $10 \mathrm{ml}$ sterile distilled water and was stored at $-70^{\circ} \mathrm{C}$ for future use.

Determination of cell viability. Cell viability was measured by conventional MTT reduction assay. The cultured cells were seeded at an initial density of $5 \times 10^{4}$ cells $/ \mathrm{ml}$ in a 96-well plate for $24 \mathrm{~h}$ and pre-incubated with 400, 500 and $600 \mu \mathrm{M}$ CPS for $2 \mathrm{~h}$ and exposed to $400 \mu \mathrm{M} \mathrm{H}_{2} \mathrm{O}_{2}$ for $2 \mathrm{~h}$. Following incubation, $20 \mu \mathrm{l}$ MTT stock solution $(5 \mathrm{mg} / \mathrm{ml})$ was added into each well at a final concentration of $0.5 \mathrm{mg} / \mathrm{ml}$ for another $4 \mathrm{~h}$. The resulting formazan was dissolved in $150 \mu \mathrm{l}$ DMSO and measured with a microtiter plate reader at a wavelength of $492 \mathrm{~nm}$.

Detection of ROS. The intracellular ROS was detected by H2DCF-DA, an oxidation-sensitive fluorescent probe. Cells were pre-incubated with CPS for $2 \mathrm{~h}$ and exposed to $400 \mu \mathrm{M}$ $\mathrm{H}_{2} \mathrm{O}_{2}$ for $2 \mathrm{~h}$. The medium was removed; cells were washed twice with serum-free medium and incubated with H2DCF-DA $(10 \mu \mathrm{M})$ for $20 \mathrm{~min}$ at $37^{\circ} \mathrm{C}$ in the dark. The fluorescence intensity was monitored on an automatic fluorescence microplate reader with an excitation wavelength of $488 \mathrm{~nm}$ and an emission wavelength of $525 \mathrm{~nm}$ and observed under a fluorescence microscope. Data were expressed as a percentage of the control.

Detection of ATP levels. Intracellular ATP levels were measured by a firefly-luciferase-based ATP detection kit (Beyotime) according to the manufacturer's instructions. Briefly, cells were seeded into the 24-well plates and washed with phosphate-buffered saline (PBS) three times. The supernatant of samples was collected immediately on ice and measured with an illuminometer. ATP levels were calculated according to an ATP standard curve. Intracellular ATP levels were analyzed as the percentage of the control group.

Measurement of MMP. The intracellular MMP was evaluated by use of the fluorescent, lipophilic and cationic probe, 5,5',6,6'-tetrachloro-1,1',3,3'-iodide (JC-1) (Beyotime) according to the manufacturer's instructions. Briefly, following treatment, the cells were loaded with JC-1 staining solution for $20 \mathrm{~min}$ at $37^{\circ} \mathrm{C}$ and washed three times with JC-1 staining buffer. The fluorescence intensity was measured by a CytoFluor multiwell plate reader with $514 \mathrm{~nm}$ for excitation and $529 \mathrm{~nm}$ for emission of green (monomer form) fluorescence, and $585 \mathrm{~nm}$ for excitation and $590 \mathrm{~nm}$ for emission for red (aggregate form) fluorescence. The MMP of cells in each group was evaluated as the fluorescence ratio of red to green and observed by a fluorescence microscope. The data were expressed as the percentage of the control.

Immunofluorescence. Cells were placed on cover slips in 24-well plates and pretreated with CPS for $2 \mathrm{~h}$ prior to exposure to $400 \mu \mathrm{M} \mathrm{H}_{2} \mathrm{O}_{2}$ for $2 \mathrm{~h}$. After washing with PBS, the slides were fixed in $4 \%$ paraformaldehyde for $10 \mathrm{~min}$ at room temperature, washed three times with PBS, permeabilized with $0.1 \%$ saponin, blocked with $10 \%$ normal goat serum and incubated overnight at $4{ }^{\circ} \mathrm{C}$ with anti-Cyt $\mathrm{C}$. The slides were incubated with FITC-conjugated goat anti-rabbit immunoglobulin (Sigma-Aldrich) for $2 \mathrm{~h}$. Nuclei were stained with Hoechst 33258 (Beyotime). Cover slips were observed under a fluorescence microscope (Leica Microsystems, Wetzlar, Germany) equipped with a Leica DFC420 camera.

Western blot analysis. Cells were lysed in SDS buffer supplemented with a mixture of protease inhibitors, $1 \mu \mathrm{g} / \mathrm{ml}$ aprotinin and $100 \mu \mathrm{g} / \mathrm{ml}$ phenylmethylsulfonyl fluorides. The cell suspension was incubated on ice for $30 \mathrm{~min}$ then centrifuged at $20,000 \mathrm{x} \mathrm{g}$ for $15 \mathrm{~min}$ at $4^{\circ} \mathrm{C}$. The supernatant was collected for further analysis. The protein concentrations of the supernatants were determined using the Bradford method. Cell lysates were denatured for $15 \mathrm{~min}$ in $5 \mathrm{X}$ sample buffer and separated by SDS-polyacrylamide gel electrophoresis. For western blot analysis, the gel was transferred onto nitrocellulose membranes using a tank transfer system. Blotted membranes were placed in a blocking solution of 5\% nonfat milk in Trisbuffered saline Tween-20 (TBS-T). For immunodetection, membranes were incubated for $1 \mathrm{~h}$ at room temperature and then incubated overnight at $4^{\circ} \mathrm{C}$ with the relevant primary 
A

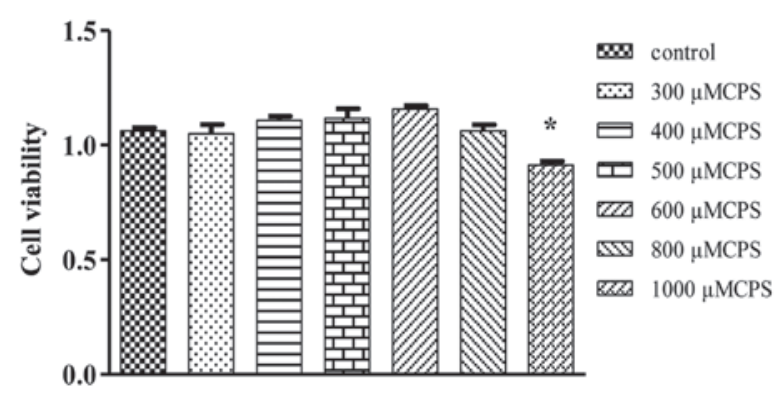

B

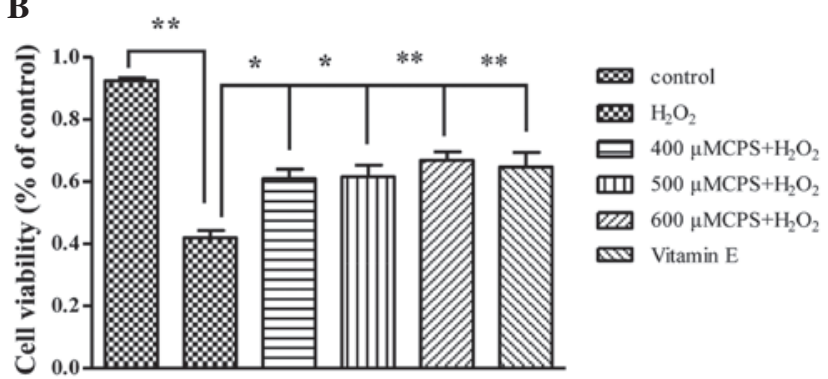

C
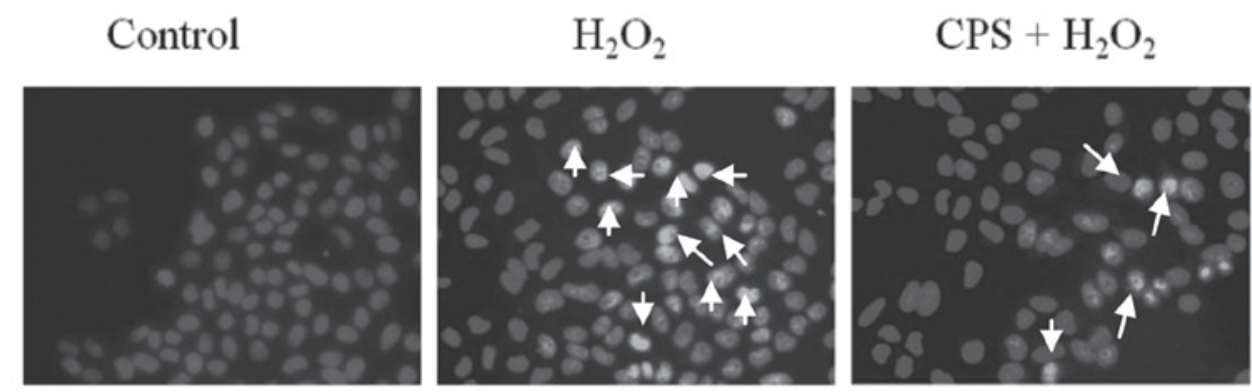

D

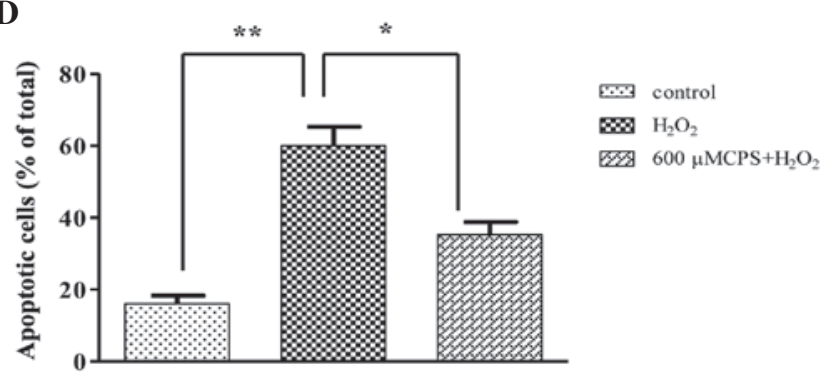

Figure 1. CPS prevented $\mathrm{H}_{2} \mathrm{O}_{2}$-induced cell apoptosis. HL-7702 cells exposed to CPS in the (A) absence or (B) presence of $\mathrm{H}_{2} \mathrm{O}_{2}$ in vitro. Cells were treated with or without CPS $(400,500,600 \mu \mathrm{g} / \mathrm{ml})$ for $2 \mathrm{~h}$, followed by incubation with $400 \mu \mathrm{M} \mathrm{H}_{2} \mathrm{O}_{2}$ for another $2 \mathrm{~h}$. After incubation, cell viability was determined with the MTT assay. (C) HL-7702 cells pretreated with or without CPS for $2 \mathrm{~h}$ were incubated with $\mathrm{H}_{2} \mathrm{O}_{2}$ for $2 \mathrm{~h}$, and then subjected to Hoechst 33258 staining and observed under a fluorescence microscope (magnification, x400). Arrows indicate apoptotic cells. (D) Quantification of apoptotic cells after exposure to $\mathrm{H}_{2} \mathrm{O}_{2}$ in the presence or absence of CPS. All data expressed as the percentage of control values are means \pm SEM $(n=6)$ from three independent experiments $\left({ }^{*} \mathrm{P}<0.05,{ }^{* *} \mathrm{P}<0.01\right)$. CPS, Cordyceps polysaccharide; $\mathrm{H}_{2} \mathrm{O}_{2}$, hydrogen peroxide.

43.3\% after treatment with $\mathrm{H}_{2} \mathrm{O}_{2}$ for $2 \mathrm{~h}$ compared with the control group. However, pretreatment with CPS significantly enhanced cell viability from 43.3 to $58.5,52.1$ and $54.9 \%$, respectively (Fig. 1B), while Vitamin E (VE) serving as a control showed a protection of $56.2 \%$. In addition, the effects were also observed under Hoechst 33258 staining, which revealed contracted nucleus and condensed chromatin fragments. Following treatment with $\mathrm{H}_{2} \mathrm{O}_{2}$ for $2 \mathrm{~h}$, the number of apoptotic cells increased compared to the control. However, pretreatment with CPS significantly decreased the number of apoptotic cells (Fig. 1C and D). These results suggested that CPS inhibits cell apoptosis induced by $\mathrm{H}_{2} \mathrm{O}_{2}$, which may be correlated with scavenging free radicals. Therefore, we further measured the eliminating capacity of CPS.

CPS ameliorated $\mathrm{H}_{2} \mathrm{O}_{2}$-induced oxidative stress. ROS generation is an important indicator of oxidative stress-induced mitochondrial dysfunction. In order to detect the capability of CPS scavenging free radicals, the H2DCF-DA assay was used to detect the generation of intracellular ROS induced by $400 \mu \mathrm{M} \mathrm{H}_{2} \mathrm{O}_{2}$ for $2 \mathrm{~h}$. The fluorescence images showed that green fluorescence intensity markedly increased when HL-7702 cells were incubated with $400 \mu \mathrm{M} \mathrm{H}_{2} \mathrm{O}_{2}$ for $2 \mathrm{~h}$. However, pretreatment with CPS reduced the green fluorescence intensity (Fig. 2A). Fig. 2B shows the same result: exposure of HL-7702 cells to $\mathrm{H}_{2} \mathrm{O}_{2}$ led to an increase of the intracellular ROS levels, which was approximately 1.39 -fold relative to $400 \mu \mathrm{M} \mathrm{H}_{2} \mathrm{O}_{2}$ for $2 \mathrm{~h}$ with or without different concentratio of CPS. The findings showed that cell viability decreased to 
A

Control
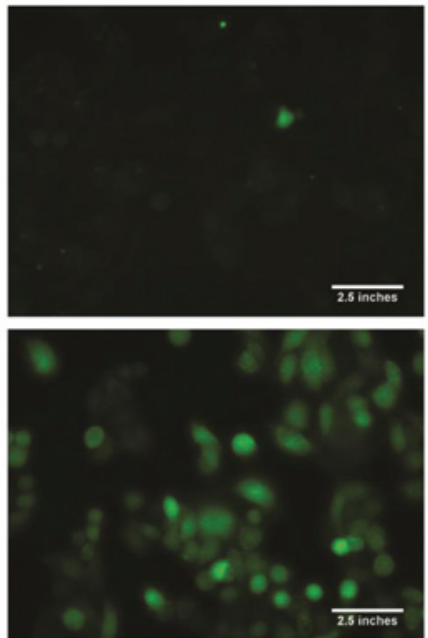

$\mathrm{CPS}+\mathrm{H}_{2} \mathrm{O}_{2}$
B

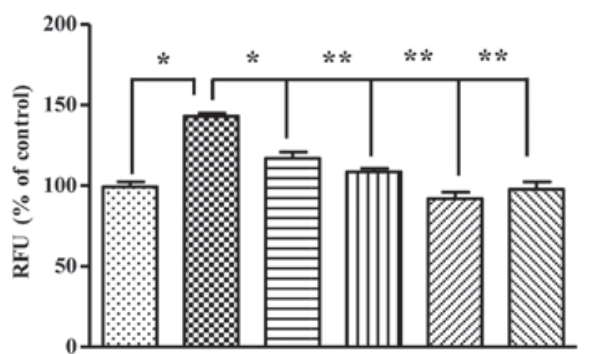

control

$\otimes \mathrm{H}_{2} \mathrm{O}_{2}$

■ $400 \mu \mathrm{MCPS}+\mathrm{H}_{2} \mathrm{O}$

س $500 \mu \mathrm{MCPS}+\mathrm{H}_{2} \mathrm{O}$

ש2 $600 \mu \mathrm{MCPS}+\mathrm{H}_{2} \mathrm{O}_{2}$

Vitamin E

$\mathbf{A}$

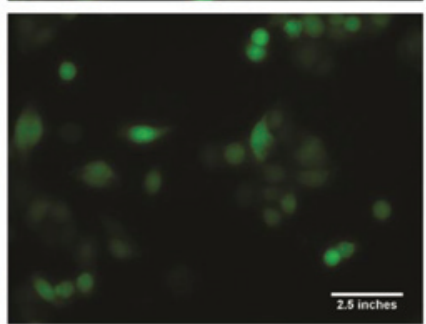

Figure 2. CPS ameliorated $\mathrm{H}_{2} \mathrm{O}_{2}$-induced ROS. (A) HL-7702 cells were preincubated with CPS for $2 \mathrm{~h}$ in the absence or presence of $\mathrm{H}_{2} \mathrm{O}_{2}(400 \mu \mathrm{M})$ and ROS were evaluated by the oxidation of H2DCF-DA to DCF. Intracellular ROS were determined using a fluorescence microscope (magnification, x400). (B) Intracellular ROS were determined by an automatic fluorescence microplate reader. Results are expressed as the means \pm SEM from three independent experiments $\left({ }^{*} \mathrm{P}<0.05,{ }^{* *} \mathrm{P}<0.01\right)$. CPS, Cordyceps polysaccharide; $\mathrm{H}_{2} \mathrm{O}_{2}$, hydrogen peroxide; ROS, reactive oxygen species.

$\mathrm{VE}++\mathrm{H}_{2} \mathrm{O}_{2}$

Monomer
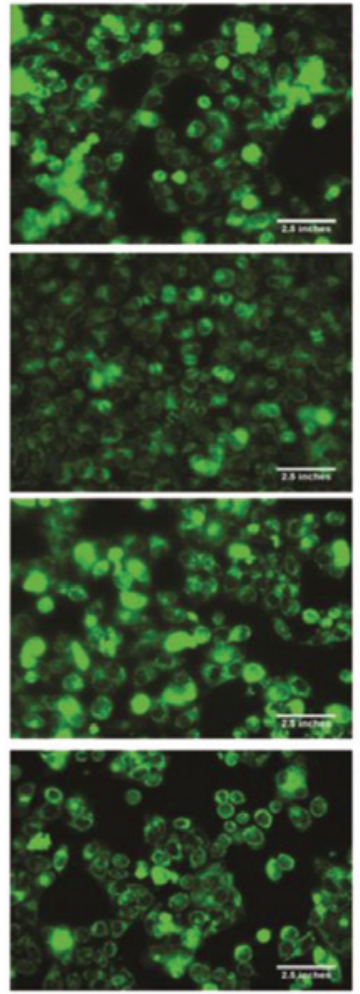

Aggregate
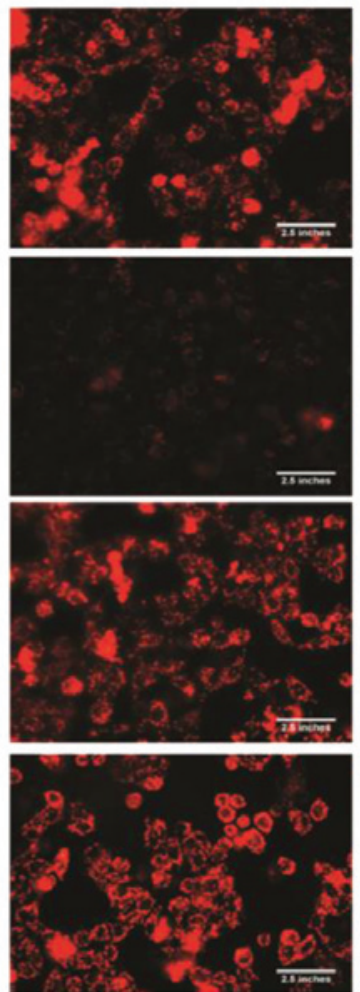

Merge

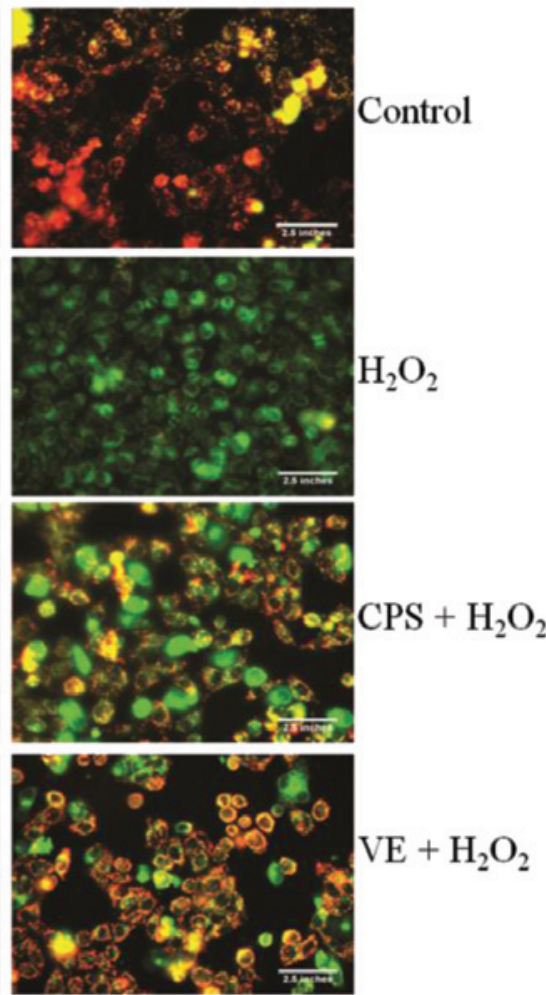

B

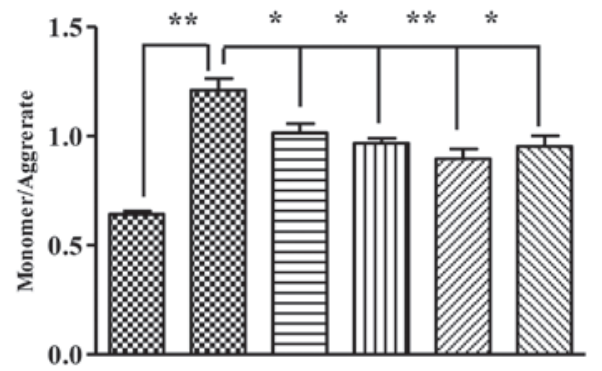

$\infty$ control

$\mathrm{H}_{2} \mathrm{O}_{2}$

$400 \mu \mathrm{MCPS}+\mathrm{H}_{2} \mathrm{O}_{2}$

س $500 \mu \mathrm{MCPS}+\mathrm{H}_{2} \mathrm{O}_{2}$

ש2 $600 \mu \mathrm{MCPS}+\mathrm{H}_{2} \mathrm{O}_{2}$

Vitamin E
Figure 3. CPS prevented $\mathrm{H}_{2} \mathrm{O}_{2}$-induced mitochondrial membrane potential (MMP). (A) HL-7702 cells were pre-incubated with CPS for $2 \mathrm{~h}$ in the absence or presence of $\mathrm{H}_{2} \mathrm{O}_{2}(400 \mu \mathrm{M})$ and the MMP was evaluated using JC-1. MMP was determined using a fluorescence microscope (magnification, x400). (B) MMP was determined by an automatic fluorescence microplate reader. Results are expressed as the means \pm SEM from three independent experiments $\left({ }^{*} \mathrm{P}<0.05,{ }^{* *} \mathrm{P}<0.01\right)$. CPS, Cordyceps polysaccharide; $\mathrm{H}_{2} \mathrm{O}_{2}$, hydrogen peroxide. 


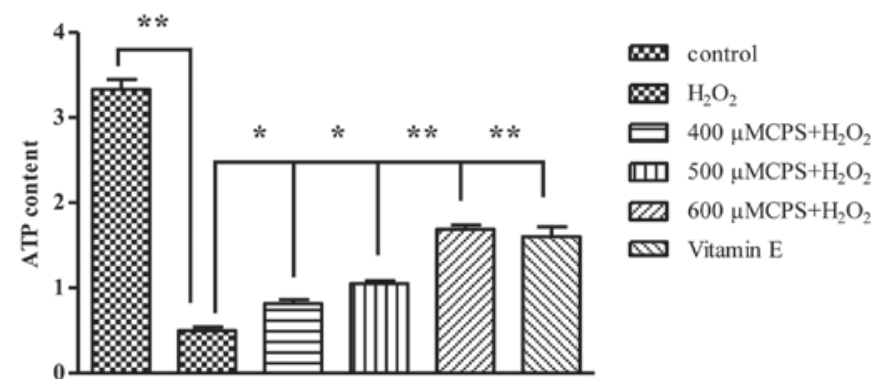

Figure 4. Effect of CPS on intracellular adenosine triphosphate (ATP) level in $\mathrm{H}_{2} \mathrm{O}_{2}$-induced HL-7702 cells. Cellular ATP concentrations were measured using firefly luciferase. Results are expressed as the means \pm SEM from three independent experiments $\left({ }^{*} \mathrm{P}<0.05,{ }^{* *} \mathrm{P}<0.01\right)$. CPS , Cordyceps polysaccharide; $\mathrm{H}_{2} \mathrm{O}_{2}$, hydrogen peroxide.

that of control cells. Pretreatment with CPS and VE inhibited the intracellular ROS level. These results suggested that CPS restrains $\mathrm{H}_{2} \mathrm{O}_{2}$-induced cell apoptosis by eliminating intracellular ROS, and mitochondrial membranes are key action sites of ROS. Therefore, we further detected the effect of CPS on mitochondrial membrane potential and energy synthesis.

CPS improved MMP. Dissipation of mitochondrial integrity is one of the early events leading to apoptosis (19). To assess whether CPS affects the function of mitochondria, the changes of MMP were analyzed by employing mitochondria fluorescence dye, JC-1, which stains mitochondria in a membrane potential-dependent manner. As shown in Fig. 3A, cells exposed to $400 \mu \mathrm{M} \mathrm{H}_{2} \mathrm{O}_{2}$ for $2 \mathrm{~h}$ resulted in a significant decrease in aggregate and increase in monomer forms; however, pretreatment with CPS prevented the loss of aggregate and the increase of the monomer forms. In addition, the effects of CPS on $\mathrm{H}_{2} \mathrm{O}_{2}$-induced MMP disruption were also confirmed by an automatic fluorescence microplate reader. Exposure to $\mathrm{H}_{2} \mathrm{O}_{2}$ for $2 \mathrm{~h}$ gave rise to a decrease in the ratio of aggregate to monomer, and 400, 500 and $600 \mu \mathrm{M}$ CPS prevented the decrease of the ratio between aggregate and monomer in a concentration-dependent manner. VE also increased the ratio between aggregate and monomer forms (Fig. 3B). These results implied that CPS attenuated $\mathrm{H}_{2} \mathrm{O}_{2}$-induced MMP dissipation.

Effect of CPS on intracellular ATP level in $\mathrm{H}_{2} \mathrm{O}_{2}$-induced $H L-7702$ cells. In order to determine whether the dysfunction of mitochondrial energy generated occurred in $\mathrm{H}_{2} \mathrm{O}_{2}$-treated cells, we investigated the changes of intracellular ATP content in the $\mathrm{H}_{2} \mathrm{O}_{2}$-treated cells with and without various concentrations of CPS (400-600 $\mu \mathrm{M})$. As shown in Fig. 4A, when HL-7702 cells were treated with $400 \mu \mathrm{M} \mathrm{H}_{2} \mathrm{O}_{2}$ for $2 \mathrm{~h}$, ATP concentration markedly decreased to $0.465 \mu \mathrm{M}$ (the concentration of control group was $4.537 \mu \mathrm{M})$. However, pretreatment

\section{Cyt C}
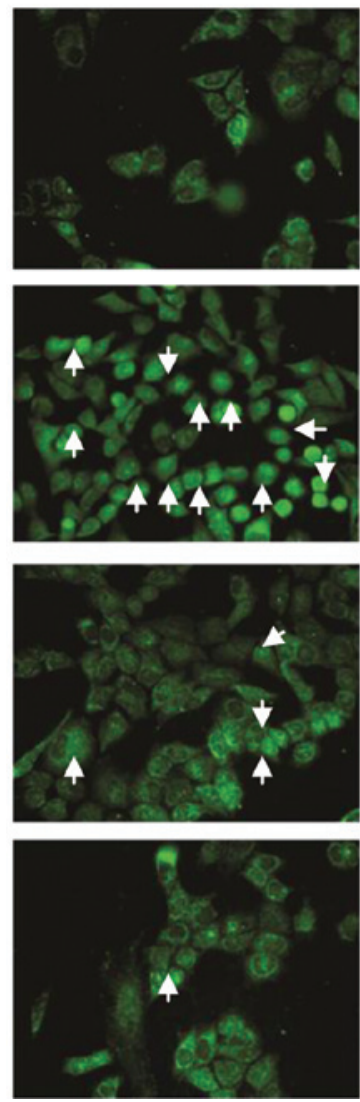

Nuclear
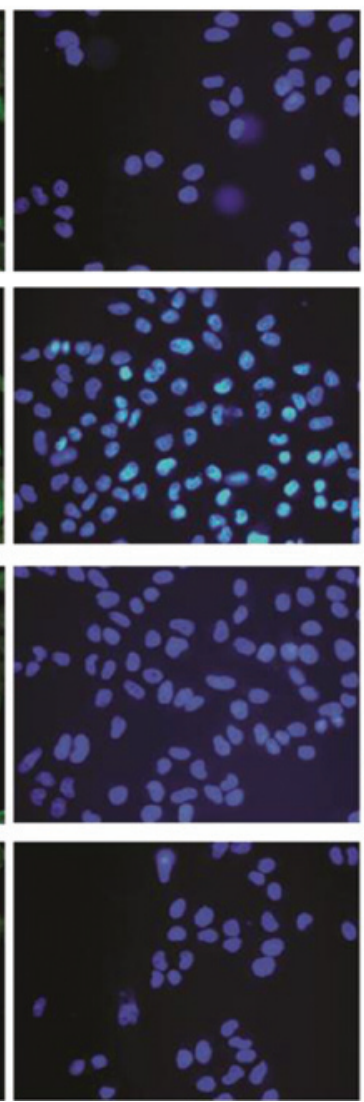

Merge

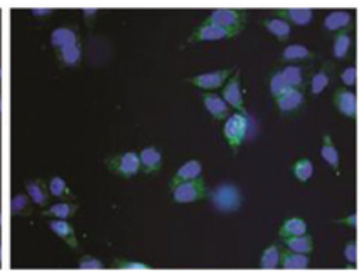

\section{Control}

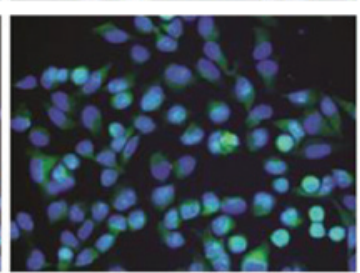

$\mathrm{H}_{2} \mathrm{O}_{2}$

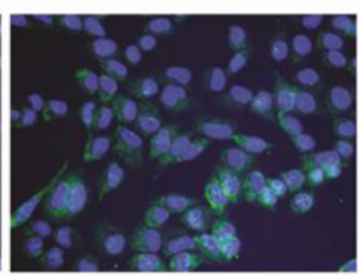

$$
\mathrm{CPS}+\mathrm{H}_{2} \mathrm{O}_{2}
$$

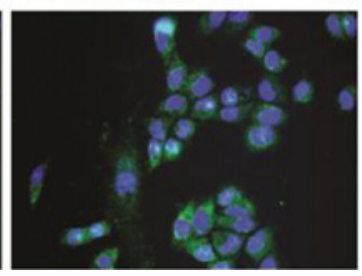

$\mathrm{VE}+\mathrm{H}_{2} \mathrm{O}_{2}$

Figure 5. Effect of CPS on the release of Cyt C induced by $\mathrm{H}_{2} \mathrm{O}_{2}$. HL-7702 cells exposed to $\mathrm{H}_{2} \mathrm{O}_{2}(400 \mu \mathrm{M})$ for 2 h with or without CPS. Cyt C was detected by immunofluorescence, imaged using a fluorescence microscope (magnification, $\mathrm{x} 400$ ). Arrows indicate the cells with $\mathrm{Cyt} \mathrm{C}$ release. The results were acquired from three independent experiments $\left({ }^{*} \mathrm{P}<0.05,{ }^{* *} \mathrm{P}<0.01\right)$. CPS, Cordyceps polysaccharide; $\mathrm{H}_{2} \mathrm{O}_{2}$, hydrogen peroxide; Cyt $\mathrm{C}$, cytochrome $\mathrm{C}$; VE, vitamin $\mathrm{E}$. 
A

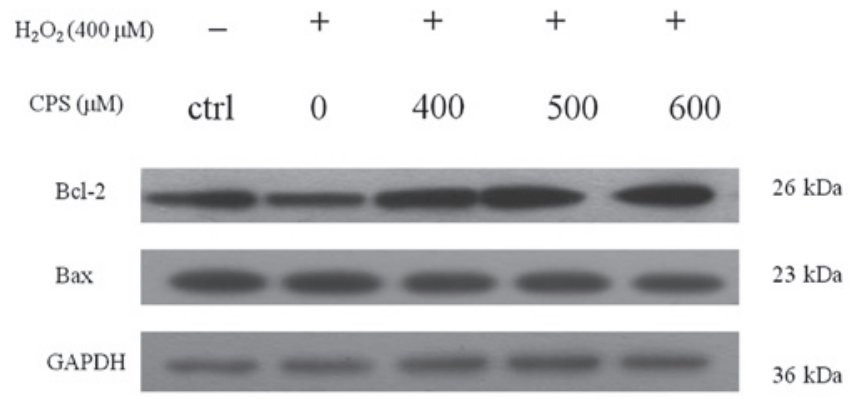

B

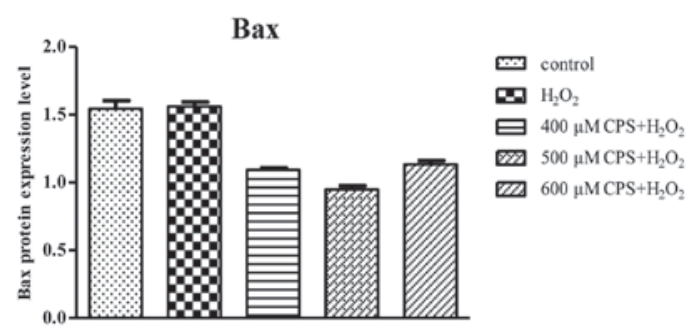

C

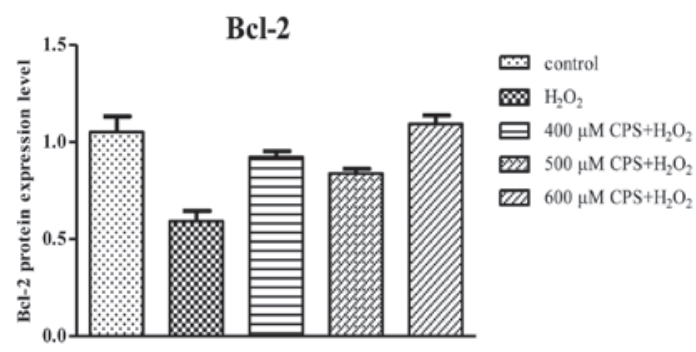

D

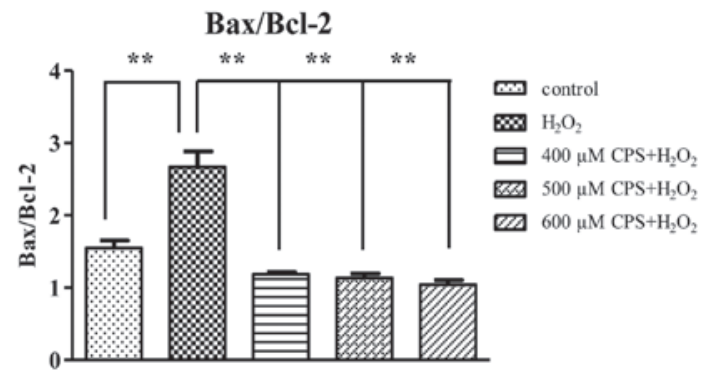

Figure 6. Effect of CPS on the expression of Bcl-2 family proteins in $\mathrm{H}_{2} \mathrm{O}_{2}$-induced HL-7702 cells. The cells were pretreated with CPS for $2 \mathrm{~h}$ prior to exposure to $400 \mu \mathrm{M} \mathrm{H}_{2} \mathrm{O}_{2}$ for $2 \mathrm{~h}$. (A) Assessment of Bax, Bcl-2 and $\mathrm{Bax} / \mathrm{Bcl}-2$ protein levels in HL-7702 cells by western blotting. The alteration of Bax was small, and Bcl-2 had an apparent change. (B and C) Quantitative analysis of Bax and Bcl-2 protein expression after normalization to GAPDH by Quantity One software. (D) The ratio of Bax/Bcl-2 decreased following treatment with CPS. The results were acquired from three independent experiments $\left({ }^{*} \mathrm{P}<0.05,{ }^{* *} \mathrm{P}<0.01\right)$. CPS, Cordyceps polysaccharide; $\mathrm{H}_{2} \mathrm{O}_{2}$, hydrogen peroxide.

with CPS (400, 500 and $600 \mu \mathrm{M})$ increased the ATP concentrations from 0.456 to $0.799,1.085$ and $1.722 \mu \mathrm{M}$, respectively, and VE inhibited the decrease of ATP levels induced by $\mathrm{H}_{2} \mathrm{O}_{2}$. Our data implied that CPS avoids the mitochondrial energy dysfunction induced by $\mathrm{H}_{2} \mathrm{O}_{2}$.

Effect of $\mathrm{CPS}$ on $\mathrm{H}_{2} \mathrm{O}_{2}$-induced $\mathrm{Cyt} \mathrm{C}$ release. Cyt $\mathrm{C}$ release from the mitochondria to the cytosol is a critical event in the mitochondrial dysfunction induced by various types of cell stress. We therefore examined whether CPS has a significant role in regulating the release of Cyt $\mathrm{C}$ using immunofluorescence staining. As shown in Fig. 5, following treatment with $400 \mu \mathrm{M} \mathrm{H}_{2} \mathrm{O}_{2}$ for $2 \mathrm{~h}$, diffuse cytoplasmic staining was detected, implying that $\mathrm{Cyt} \mathrm{C}$ was released from the mitochondria to the cytosol. Moreover, pretreatment with $600 \mu \mathrm{M}$ CPS prevented the Cyt $\mathrm{C}$ release from the mitochondria to the cytosol caused by $\mathrm{H}_{2} \mathrm{O}_{2}$. The data demonstrated that Cyt $\mathrm{C}$ is a key apoptotic factor in the mitochondrial-dependent apoptotic pathway, and CPS inhibits cell apoptosis by regulating mitochondrial apoptotic factors, such as Cyt C. Consequently, we further observed whether CPS was capable of accommodating other apoptosis-related factors.

Effect of CPS on the expression of Bcl-2 family proteins in $\mathrm{H}_{2} \mathrm{O}_{2}$-induced $\mathrm{HL}-7702$ cells. Bcl-2 family membranes play critical roles in maintaining mitochondrial integrity and mitochondria-initiated $\mathrm{Cyt} \mathrm{C}$ release. Previous studies have reported that the ratio of the pro-apoptotic protein Bax to the anti-apoptotic Bcl-2 was correlated with cell apoptosis (20). Our results showed that the protein level of Bax displayed little change and there was a prominent decrease in the protein expression of Bcl-2 after HL-7702 cell treatment with $400 \mu \mathrm{M}$ $\mathrm{H}_{2} \mathrm{O}_{2}$, and there was an approximate 1.9-fold increase in the ratio of $\mathrm{Bax} / \mathrm{Bcl}-2$ in the $\mathrm{H}_{2} \mathrm{O}_{2}$ treatment group compared with the control group, as shown by western blot analysis. However, CPS inhibited the $\mathrm{H}_{2} \mathrm{O}_{2}$-induced increase of Bax/Bcl-2 ratio in a concentration-dependent manner (Fig. 6A-D). The effect of CPS on $\mathrm{H}_{2} \mathrm{O}_{2}$-induced apoptosis may be, at least in part, mediated by the regulation of $\mathrm{Bax}$ and $\mathrm{Bcl}-2$ expression. CPS decreased the ratio of $\mathrm{Bax} / \mathrm{Bcl}-2$ and suggested that it may suppress the mitochondrial-dependent apoptosis induced by $\mathrm{H}_{2} \mathrm{O}_{2}$.

\section{Discussion}

$\mathrm{H}_{2} \mathrm{O}_{2}$ is extensively used as an indicator of oxidative stress inducing cell injury in a number of in vitro models. It is now well known that $\mathrm{H}_{2} \mathrm{O}_{2}$ is able to react with intracellular metal ions (iron or copper) creating highly toxic hydroxyl radicals that cause cell damage (21). The $\mathrm{H}_{2} \mathrm{O}_{2}$-induced cytotoxicity has been reported to be attenuated by antioxidants and free radical scavengers $(22,23)$. The present study provides evidence that CPS significantly prevented $\mathrm{H}_{2} \mathrm{O}_{2}$-induced hepatocyte injury in HL-7702 cells, potentially through antioxidant and antiapoptotic mechanisms. Several studies have reported that CPS displays potent antioxidant properties through increasing the activities of CAT, SOD and GPx $(14,24)$. The present results showed that $\mathrm{H}_{2} \mathrm{O}_{2}$ induced a decrease in cell viability, whereas different concentrations of CPS were able to significantly inhibit cell injury by increasing cell viability (Fig. 1). Taken together, these results demonstrated that $\mathrm{H}_{2} \mathrm{O}_{2}$ is capable of leading to HL-7702 cell injury and CPS has a hepatoprotective effect against $\mathrm{H}_{2} \mathrm{O}_{2}$-induced HL-7702 cell injury.

Powerful evidence showed that oxidative damage leads to mitochondrial dysfunction, which plays critical roles in hepatocyte toxicity (25). ROS are chiefly produced in the mitochondria and contribute to intracellular signaling processes and then regulate various biological activities including cell apoptosis (26). The present study demonstrated 
that $\mathrm{H}_{2} \mathrm{O}_{2}$ induces intracellular ROS generation, whereas CPS is capable of inhibiting cell apoptosis by scavenging intracellular ROS. Excessive ROS are known to induce the collapse of MMP, which is an important event in mitochondrial dysfunction (27). CPS restrained the loss of MMP induced by $\mathrm{H}_{2} \mathrm{O}_{2}$ and the results showed that CPS protects HL-7702 cells against $\mathrm{H}_{2} \mathrm{O}_{2}$-induced mitochondrial dysfunction. ROS overproduction lead to free radical attack of mitochondrial membrane phospholipids following the reduction of MMP, which caused the release of pro-apoptotic factors, such as Cyt $\mathrm{C}$, from the mitochondrial intermembrane space to the cytosol, and induced cell apoptosis by activating downstream factor caspase-3 (28). In accordance with these theories, the present study showed that CPS prevented the release of Cyt C from the mitochondria to the cytosol induced by $\mathrm{H}_{2} \mathrm{O}_{2}$. It is well known that mitochondria are the key site of ATP cellular energy metabolism, oxidative phosphorylation is the major ATP synthetic pathway, and complexes I-IV constitute the respiratory chain. When a $\mathrm{H}^{+}$gradient was established across the mitochondrial double membrane, complex IV derived ATP synthesis occurred (29). Our results showed that cells treated with $\mathrm{H}_{2} \mathrm{O}_{2}$ showed a decrease in ATP level; however, pretreatment with CPS may elevate intracellular ATP content. The potent antioxidant of CPS protects HL-7702 cells against mitochondrial dysfunction.

The Bcl-2 family of proteins are important participants in the mitochondrial apoptotic pathway, and play a critical role in regulating the interaction between pro-apoptotic proteins and anti-apoptotic proteins to determine the life or death of cells $(30,31)$. In normal cells, anti-apoptotic proteins, such as $\mathrm{Bcl}-2$, are mainly located in the mitochondrial outer membrane while pro-apoptotic proteins, such as Bax, primarily exist in the cytoplasm (32). Apoptotic factors acting on the mitochondria triggered Bax to translocate to the mitochondrial outer membrane and homodimerize, resulting in the release of apoptosis-inducing factors (33). Bax then translocates to the mitochondrial membrane where it interacts with the antiapoptotic protein $\mathrm{Bcl}-2$, inhibits Bcl-2 ability and promotes apoptosis. Therefore, alteration of the ratio of $\mathrm{Bax}$ and $\mathrm{Bcl}-2$ influences cell apoptosis (34). Our data demonstrated that HL-7702 cells treated with $\mathrm{H}_{2} \mathrm{O}_{2}$ increased the ratio of Bax/ $\mathrm{Bcl}-2$; however, CPS decreased the ratio of $\mathrm{Bax} / \mathrm{Bcl}-2$. These results suggested that CPS inhibited HL-7702 cell apoptosis induced by $\mathrm{H}_{2} \mathrm{O}_{2}$ by modulating the $\mathrm{Bcl}-2$ family proteins.

In conclusion, the results of the current study demonstrate that CPS is able to ameliorate the mitochondrial dysfunction and oxidative stress induced by $\mathrm{H}_{2} \mathrm{O}_{2}$ in HL-7702 hepatocytes through increasing cell viability, attenuating intracellular ROS levels, preventing the loss of MMP, enhancing ATP content, inhibiting $\mathrm{Cyt} \mathrm{C}$ release from mitochondria to cytosol and decreasing the ratio of $\mathrm{Bax} / \mathrm{Bcl}-2$. Although more detailed mechanistic investigations should be undertaken to clarify the mitochondrial protection of CPS, these results imply that the antioxidant CPS has promising potential to be used in treating hepatic diseases that involve free radical and oxidative injury.

\section{Acknowledgements}

This study was supported by National Science and Technology Major Project of China (2009ZX09311-003).

\section{References}

1. Friedman SL: Liver fibrosis - from bench to bedside. J Hepatol 38 Suppl 1: S38-53, 2003

2. Koek GH, Liedorp PR and Bast A: The role of oxidative stress in non-alcoholic steatohepatitis. Clin Chim Acta 412: 1297-1305, 2011.

3. Yan X, Zhou T, Tao Y, Wang Q, Liu P and Liu C: Salvianolic acid $\mathrm{B}$ attenuates hepatocyte apoptosis by regulating mediators in death receptor and mitochondrial pathways. Exp Biol Med (Maywood) 235: 623-632, 2010.

4. Park NS, Lee KS, Sohn HD, Kim DH, Lee SM, Park E, Kim I, Je YH and Jin BR: Molecular cloning, expression, and characterization of the $\mathrm{Cu}, \mathrm{Zn}$ superoxide dismutase (SOD1) gene from the entomopathogenic fungus Cordyceps militaris. Mycologia 97: 130-138, 2005.

5. Chen YJ, Shiao MS, Lee SS and Wang SY: Effect of Cordyceps sinensis on the proliferation and differentiation of human leukemic U937 cells. Life Sci 60: 2349-2359, 1997.

6. Xiao JH, Liang ZQ and Liu AY: Advances of polysaccharides research and exploitation of anamorph and its related fungi from Cordyceps. Yao Xue Xue Bao 37: 589-592, 2002 (In Chinese).

7. Ohta Y, Lee JB, Hayashi K, Fujita A, Park DK and Hayashi T: In vivo anti-influenza virus activity of an immunomodulatory acidic polysaccharide isolated from Cordyceps militaris grown on germinated soybeans. J Agric Food Chem 55: 10194-10199, 2007.

8. Nakamura K, Yamaguchi Y, Kagota S, Shinozuka K and Kunitomo M: Activation of in vivo Kupffer cell function by oral administration of Cordyceps sinensis in rats. Jpn J Pharmacol 79: 505-508, 1999.

9. Kiho T, Ookubo K, Usui S, Ukai S and Hirano K: Structural features and hypoglycemic activity of a polysaccharide (CS-F10) from the cultured mycelium of Cordyceps sinensis. Biol Pharm Bull 22: 966-970, 1999.

10. Koh JH, Kim JM, Chang UJ and Suh HJ: Hypocholesterolemic effect of hot-water extract from mycelia of Cordyceps sinensis. Biol Pharm Bull 26: 84-87, 2003.

11. Yamaguchi Y, Kagota S, Nakamura K, Shinozuka K and Kunitomo M: Antioxidant activity of the extracts from fruiting bodies of cultured Cordyceps sinensis. Phytother Res 14: 647-649, 2000 .

12. Li SP, Su ZR, Dong TT and Tsim KW: The fruiting body and its caterpillar host of Cordyceps sinensis show close resemblance in main constituents and anti-oxidation activity. Phytomedicine 9: 319-324, 2002

13. Li SP, Zhao KJ, Ji ZN, Song ZH, Dong TT, Lo CK, Cheung JK, Zhu SQ and Tsim KW: A polysaccharide isolated from Cordyceps sinensis, a traditional Chinese medicine, protects PC12 cells against hydrogen peroxide-induced injury. Life Sci 73: $2503-2513,2003$

14. Li XT, Li HC, Li CB, Dou DQ and Gao MB: Protective effects on mitochondria and anti-aging activity of polysaccharides from cultivated fruiting bodies of Cordyceps militaris. Am J Chin Med 38: 1093-1106, 2010.

15. Zamzami N, Marchetti P, Castedo M, Zanin C, Vayssiere JL, Petit PX and Kroemer G: Reduction in mitochondrial potential constitutes an early irreversible step of programmed lymphocyte death in vivo. J Exp Med 181: 1661-1672, 1995.

16. Preston TJ, Abadi A, Wilson L and Singh G: Mitochondrial contributions to cancer cell physiology: potential for drug development. Adv Drug Deliv Rev 49: 45-61, 2001.

17. Cadenas E and Davies KJ: Mitochondrial free radical generation, oxidative stress, and aging. Free Radic Biol Med 29: 222-230, 2000.

18. Raha S and Robinson BH: Mitochondria, oxygen free radicals, disease and ageing. Trends Biochem Sci 25: 502-508, 2000.

19. Rasola A and Bernardi P: The mitochondrial permeability transition pore and its involvement in cell death and in disease pathogenesis. Apoptosis 12: 815-833, 2007.

20. Wang H, Xu Y, Yan J, Zhao X, Sun X, Zhang Y, Guo J and Zhu C: Acteoside protects human neuroblastoma SH-SY5Y cells against beta-amyloid-induced cell injury. Brain Res 1283: 139-147, 2009.

21. Naval MV, Gomez-Serranillos MP, Carretero ME and Villar AM: Neuroprotective effect of a ginseng (Panax ginseng) root extract on astrocytes primary culture. J Ethnopharmacol 112: 262-270, 2007.

22. Hong $\mathrm{H}$ and Liu GQ: Protection against hydrogen peroxideinduced cytotoxicity in PC12 cells by scutellarin. Life Sci 74: 2959-2973, 2004. 
23. Liu CS, Chen NH and Zhang JT: Protection of PC12 cells from hydrogen peroxide-induced cytotoxicity by salvianolic acid B, a new compound isolated from Radix Salviae miltiorrhizae. Phytomedicine 14: 492-497, 2007.

24. Guizani N, Waly MI, Ali A, Al-Saidi G, Singh V, Bhatt N and Rahman MS: Papaya epicarp extract protects against hydrogen peroxide-induced oxidative stress in human SH-SY5Y neuronal cells. Exp Biol Med (Maywood) 236: 1205-1210, 2011.

25. Hwang JM, Cho JS, Kim TH and Lee YI: Ellagic acid protects hepatocytes from damage by inhibiting mitochondrial production of reactive oxygen species. Biomed Pharmacother 64: 264-270, 2010.

26. Rhee SG, Bae YS, Lee SR and Kwon J: Hydrogen peroxide: a key messenger that modulates protein phosphorylation through cysteine oxidation. Sci STKE 2000: pe1, 2000.

27. Park MT, Kim MJ, Kang YH, Choi SY, Lee JH, Choi JA Kang CM, Cho CK, Kang S, Bae S, Lee YS, Chung HY and Lee SJ: Phytosphingosine in combination with ionizing radiation enhances apoptotic cell death in radiation-resistant cancer cells through ROS-dependent and -independent AIF release. Blood 105: 1724-1733, 2005.
28. Bras M, Queenan B and Susin SA: Programmed cell death via mitochondria: different modes of dying. Biochemistry (Mosc) 70: 231-239, 2005

29. Loeffler M and Kroemer G: The mitochondrion in cell death control: certainties and incognita. Exp Cell Res 256: 19-26, 2000.

30. Allen RT, Pai J, Bovard K, Hunter WJ, 3rd and Agrawal DK: Immunogold staining for Bcl-xL and morphological analysis of rat and human vascular smooth muscle cells undergoing apoptosis induced by c-myc or staurosporine. Scanning 20: 207-208, 1998

31. Cory S and Adams JM: The Bcl2 family: regulators of the cellular life-or-death switch. Nat Rev Cancer 2: 647-656, 2002.

32. Song XD, Zhang JJ, Wang MR, Liu WB, Gu XB and Lv CJ: Astaxanthin induces mitochondria-mediated apoptosis in rat hepatocellular carcinoma CBRH-7919 cells. Biol Pharm Bull 34: 839-844, 2011

33. Adams JM and Cory S: The Bcl-2 protein family: arbiters of cell survival. Science 281: 1322-1326, 1998.

34. Yang SH, Chien CM, Lu MC, Lin YH, Hu XW and Lin SR: Up-regulation of Bax and endonuclease $\mathrm{G}$, and down-modulation of Bcl-XL involved in cardiotoxin III-induced apoptosis in K562 cells. Exp Mol Med 38: 435-444, 2006. 